\title{
On the Principles of English Teaching Reform in Higher Vocational Colleges Based on "The Basic Requirements of English Curriculum Teaching in Higher Vocational Colleges"
}

\author{
Huijun Liu $^{1} \&$ Yida Ning ${ }^{2}$ \\ ${ }^{1}$ Foreign Studies Department, Hunan International Business Vocational College,Changsha, Hunan Province, \\ China \\ ${ }^{2}$ Economic Department, Hunan Agricultural University,Changsha, Hunan Province, China \\ Correspondence: Huijun Liu, Foreign Studies Department, Hunan International Business Vocational College, \\ Changsha, Hunan Province, China. Tel: 86-13507406339. E-mail: 244093158@qq.com
}

Received: June 28, 2017 Accepted: July 29, 2017 Online Published: August 1, 2017

doi: 10.5539/elt.v10n9p11 URL: http://doi.org/10.5539/elt.v10n9p11

\begin{abstract}
English teaching reform is critical for the cultivation of skilled talents and the development of national economy. The paper attempts to analyze the guidance principles of English teaching reform in the higher vocational colleges underlying "the Basic Requirements of English Curriculum Teaching in Higher Vocational Colleges", promulgated by Ministry of Education of China in 2000. Specifically, the principles should be characterized by modularization, individualization, collaboration, and hypertextualization.
\end{abstract}

Keywords: principles, Basic Requirements, English teaching reform, higher vocational colleges

\section{Introduction}

It is universally acknowledged that, since the policy of reform and opening-up, English teaching in higher vocational colleges of China has made significant achievements for the cultivation of numerous highly skilled talents and the rapid development of national and sectional economy. However, due to the severe influence of the traditional mode of exam-oriented education for years, English teaching in higher vocational colleges has always been focusing on the imparting of language knowledge, ignoring language ability training, and implementing the teaching mode of "the one-way static method communication", neglecting students' initiative and personalized learning as well. So the current situation and teaching quality of English education in higher vocational colleges is worrying. With the economic integration, that is, the dramatically frequent exchanges and cooperation between China and other countries, there is a growing demand for applied foreign language talents from different fields. So in order to meet the urgent and highly qualified need of applied foreign language talents from the society, study on English teaching reform in higher vocational colleges has been a heated topic.

The author employs "the English teaching reform in higher vocational education" as the keyword to search in the website of China National Knowledge Infrastructure (CNKI), and has discovered that there are 30 published academic articles in CNKI since 2007. Among these published articles, the researchers have conducted English teaching reform in higher vocational colleges from various aspects. For instance, Liu (2015)on the basis of clarifying the definition of English for Occupational Purposes (EOP), probes into the construction path of EOP teaching reform in terms of curriculum setting, teaching content design, teaching model reform, teaching assessment adjustment and teacher's professional development. Shao (2016) believes English teaching in higher vocational colleges should be focused on cultivating students' competence in foreign language, and insists that the course teaching and vocational needs should be closely combined to enhance the students' professional ability, so that the students can become practical and popular enterprise English talents. Zhou (2011) also holds that the basic aim of higher vocational English teaching is to improve students' practical English. Therefore, much attention should be paid to the exploration of teaching materials, teachers and teaching methods in higher vocational English teaching reform, at the same time, the higher vocational English teaching is bound to deal with three sets of contradictions. Han (2011) deems that people must put the reform of English teaching for urgent attention on such aspects as changing the teaching philosophy, improving classroom teaching, optimizing course structure, strengthening the second classroom teaching and enhancing teaching staff construction etc. to 
gradually form the characteristics and advantages of higher vocational English teaching. Ning (2012) takes higher vocational English teaching reform in Guangdong Province as a case, from the perspective of the law of language teaching, social demand, teachers and students to explore EOP English teaching mode and its path. Construction. Yang (2010) thinks that Graded teaching can greatly improve the initiative of students and teachers in learning and teaching, and he attempts to probe into the mode of Graded teaching in the practice of higher vocational English teaching. Liu (2015) states clearly the position of higher vocational English teaching, aiming at the problems in higher vocational English education and combining with the training goal of higher vocational English teaching to realize the goal of higher vocational English teaching. Wei (2011) holds that the success of higher vocational English teaching reform depends on the reform in all aspects, including ideological changes, the adjustment of teaching goals and teaching orientation, the development of syllabus are the prerequisites and theoretical bases for successful reform. Liu (2015) and Zhang (2009) both take the advantage of the English Skill Competition to promote the English reform of higher vocational education. Zhang (2010) discusses the connection between philosophical prejudice and English teaching on the basis of Gadamer's philosophical Hermenthutics, to improve the teaching efficiency in English teaching in vocational colleges.

Though the previous academic researches are abundant and significant, there lie some deficiencies in these researches: (1) there are many concept clarifications and relatively few practical applications; (2) the purpose of English teaching reform is diversified; (3) the research approach is too simple, and $84 \%$ articles merely use theoretical narration; (4) the research content differs greatly. In sharp contrast, there is no record on guidance principles of English teaching reform in higher vocational colleges.Therefore, the research is of great originality and of great importance.

\section{The Principles of English Teaching Reform in Higher Vocational Colleges Based on "the Basic Requirements of English Curriculum Teaching in Higher Vocational Colleges"}

Complying with the popular English reform, "the Basic Requirements of English Curriculum Teaching in Higher Vocational Colleges"(hereinafter referred to as "Basic Requirement of 2000") was formulated by the Ministry of Education in 2000, which is the second teaching guidance document for public English teaching in higher colleges,and the first one is called "the Basic Requirements of English Course Teaching in Ordinary Colleges" (hereinafter referred to as Basic Requirements of 1993). In 1998, in order to adapt to the requirements of the new environment, the Ministry of Education organized experts to conduct the document modification, and two years later, "Basic Requirements of 2000" was issued. Different from the previous document, "Basic Requirements of 2000 " points out that the teaching purpose of English teaching in higher vocational education is to enable students to master certain basic knowledge and skills of English,and to possess certain ability of listening, speaking, reading, writing and translating.As a result, the students can read and translate materials about business English with the help of a dictionary, as well as make simple oral and written communication in the cross-cultural environment. In addition, it can lay a solid foundation for the further improvement of the English communicative ability in the future. To analyze the theme of "the Basic Requirements", we can interpret that the influential document has instructed the principles of English teaching reform for higher vocational colleges, namely, which are modularized, individualized, collaborative and hypertextualized.

\subsection{Modularization}

"Basic Requirements of 2000" vividly proposes that "we should attach great importance to the law of language learning, and correctly tackle with the relationship among listening, speaking, reading, writing and translating, to ensure the coordinated development of language skills". And "It is protocol to place special emphasis on the development of listening and speaking skills." Meanwhile, instructing and testing in teaching requirements are cataloged into level A and level B according to "the difference between the students' English standard on entry". It is difficult to achieve the goal by establishing a course or writing a textbook so that we are supposed to conduct modular teaching.

Modular teaching is an educational monograph about competence and quality. To achieve the teaching goals of the development of competence and quality as well, modular teaching puts emphasis on the combination between knowledge and competence on teaching, and the consistence between knowledge and behaviors on studying, concentrating on the synchronous integrated teaching and learning among relevant theoretical knowledge, practical experience and operational skills.

According to modular teaching, English teaching materials in higher vocational college can be classified into English reading and writing ones, thereafter be divided into several modules in accordance to the degree of difficulty. For each textbook, it can be roughly divided into modules by unit, organizing sub-modules under the theme of the text. Therefore, all materials such as learning, listening, speaking, reading and writing are under the 
same topic as a whole, and theme vocabulary and language expression can be repeated over and over again, which can eventually enhance students' memory and retention of language learning so as to cultivate their comprehensive skills containing listening, speaking, reading and writing. In each unit, we can separate it into the next three levels of sub-module according to the requirement of context, language skills and output, ultimately to make the unification among language practical knowledge, real situation and actual competence use.

Compared modular teaching with traditional teaching, it can be seen clearly that modular teaching has considerable advantages: First, on the concept of education, the traditional teaching attaches tremendous importance on the knowledge-oriented, focusing on knowledge; Whilst the module teaching highlights great significance of the competence-oriented, stressing the actual application of the knowledge and skills. Secondly, in the teaching content, the traditional teaching for the most part puts knowledge first and the skill second, which has both knowledge and skill teaching context. In contrast, the module type teaching is only one vein, and there is no strict distinction between theory course and practice course; Thirdly, in the method of teaching, traditional teaching focuses on the teaching of knowledge, and relatively speaking, its teaching method is fairly simple. On the contrary, modular teaching gives top priority on the competence and quality, and the teaching methods are more than a little various and plentiful, for instance, case teaching, discussion teaching, situational teaching and collaborative learning. Particularly, all teaching approaches are conforming to the laws of cognition and affection commitment. Therefore, on the basis of "the Basic Requirements", English teaching reform in higher vocational colleges should adopt the module teaching, since it can implement the teaching curriculum design integrated by student-centered, quality-oriented and ability-focused as well.

\subsection{Individualization}

Graded teaching is commonly mentioned in "Basic Requirements of 2000 ", such as "in view of the great differences of students' English standard between higher vocational colleges and adult college, teaching requirements of this course are divided into level A, and B", and "grade A is a standard requirement, whilst grade $\mathrm{B}$ is a transitional requirement", and "the students whose English standard are high on entry should reach the requirements of level A, and those are low on admission should at least meet the requirements of level $\mathrm{B}$. With the constant improvement, students' English should be reached level A requirements". Actually these remarks are the practice of Individualized Learning, which is on the foundation of Construction Theory. Constructionists hold that knowledge is not obtained by teachers' teaching, but learners' learned in certain situations, namely, the social and cultural background, by virtue of acquiring knowledge from others (including teachers and learning partners), using the necessary learning materials, and by the aid of meaning construction. The typical representative of Construction Theory is Psychologist Piaget (1972), who studies the cognitive development of children from the perspective of view of internal and external interactions. Children, he argues, is in the process of interaction with the surrounding environment, gradually construct knowledge about the outside world, making their own cognitive structure. The interaction between children and the environment is inextricably linked to two essential processes: "assimilation" and "adaptation". Piaget once said, "the only real ubiquitous cognitive development factors, the ontogenesis of both science and thinking, are all functional rather than structural". On this basis, psychologist Kelly (1963) brainstormed the concept of "Individual Constructed". Kelly also stressed in dealing with a learning task everyone employs different methods of individual constructing, "different people use different ways to construct the universe... therefore, through the infinite series of successfully approximation to know his world". In line with the constructive theory, in foreign language teaching, teachers should utterly respect students' choice, especially esteem their own learning styles and learning strategies, for instance, some learners are accustomed to seeing, some are used to listening, some are specialized in reading and writing, while some are are extraordinarily conversant with pragmatic ability.

Under the current situation of enrollment expansion, owing to students' different English standard, diversified learning abilities, assorted learning strategies, disparate learning motivations and common lack of teaching staff, it is particularly protocol to foster the students' individual learning ability. Students can take full advantage of the "language learning center" or "English autonomous learning center", and even in every corner of the campus to accomplish autonomous learning, for the sake of maximizing their individualized learning. At the same time, the campus network, which has broken through the traditional teaching mode of allotted space and time, also established an infinite and open teaching platform for students to study, who can study anywhere and at any time on campus, and learn how long the time is. Students can also choose different ranks of learning materials hinged upon their standard and needs, and set learning objectives and determine study process, and continuously make adjustments if necessary, ultimately making their learning targets come into great fruition. Therefore, individualized learning advocated by the "Basic Requirements of 2000" is the crux guiding the English curriculum teaching reform for higher vocational colleges. 


\subsection{Collaboration}

Such sentences are constantly emerging in "the Basic Requirements of 2000" as "English curriculum should not simply make solid language foundation, but place more stress on cultivating the actual utilization of language skills, especially the capability to tackle with the daily and foreign-related business activities" with the weapon of English and "we are required to pour sufficient importance into fostering students' ability to effectively communicate in English language." This means that learners should be taught to communicate and cooperate with each other in addition to individualized learning, which is called "collaborative learning" by psychologists and educators, and whose primary spirit is to separate students into groups so as to fulfill a common goal. This is determined by the nature of language. The concept of meta-function and interpersonal function proposed by the linguist Halliday (1985) illustrates that we utilize language both to express our thoughts and to strengthen our relationship. The former Soviet psychologist Vygotsky (1978) also talked about the idea of social cognition: namely, language is both individual and social. The core of his theory is the thought of "the zone of proximal development", namely, there are children's level of actual development determined through learning or through independently solving problems, and children's level of potential development determined under the guidance of adults or stronger companion's cooperation to solve problems, so "Adjacent Development Area" is the distance between the two. Little (1991) also pointed out that "Unobstructions young children's development study who experience, is in interactions with their family members, friends, neighbors and so forth. Education, irrespective of institutionalization, is also a social interaction and process. For most of us, do remember the importance of learning experience, at least in part, to use our relations with others, or more people, or relationship with teachers to exemplify." As you can see, language learning emphasizes individualized learning on the one hand, on the other hand stresses learners to cooperate with others. Hence, "Basic Requirements of 2000" desperately requires the higher vocational English reform to be based on the collaborative learning of mutual assistance.

\subsection{Hypertextualization}

"Basic Requirements of 2000"puts forward that "we should actively introduce and utilize modern teaching approaches such as computer multimedia and network technology, to ameliorate English teaching conditions in colleges". From here we can see that vocational English teaching will gradually transit from computer assisted instruction to multimedia and network teaching dominated by hypertext ideas.

"Hypertext" was initially adopted by an American named Ted Nelson in the national computer association's report in 1965. In 1981, Ted Nelson employed the term "hypertext" to describe the idea in his book: to create a globally influential document, and distribute various parts of the document in different servers. By activating, hypertext items can become links, such as the number of references in research papers, and you can jump to the citations. Later, Ted Nelson defined it as "a series of text blocks connected by a compact link to provide a different path to the reader." Finally, realizing the idea of hypertext was Tim berners-lee, which appeared on the Internet as the "World Wide Web" at CERN in 1989.

According to "the Basic Requirements", accordingly, English teaching model in higher vocational colleges should have the following advantages based on the idea of hypertext:

(1) the combination of large classes and small classes;

(2) the combination of classroom teaching and open autonomous learning;

(3) the combination of multimedia teaching and online teaching;

(4) the first classroom teaching is combined with the second classroom activity.

\section{Conclusion}

Nowadays, there exists an excellent opportunity for the development of higher vocational education. Whilst, the problems of public English education in higher vocational colleges are endless. Under the background of higher qualification and demand for applied English talents at home and abroad, the research on the principles of English teaching reform has both theoretical and practical significance. On one hand, it is beneficial to promoting the theoretical research of English curriculum teaching reform in higher vocational colleges in China, and inquiring the suitable teaching rules of public English in vocational colleges, to effectively impel the development of English subject construction in higher vocational college; On the other hand, It is conductive to enhance the quality of English education, highlight its "competence" characteristics, and boost the quality of students' employment, as well as cultivate students' language practical application competence and autonomous learning ability. 


\section{Limitation of the Research}

The Basic Requirements of 2000, is the most important document to guide the national public English education reform in higher vocational colleges in China. So far, there has been no research focusing on it, and this paper is just a trial one hoping to arouse the attention of scholars, so there is no denying that some limitation are found in it: (1) The current literature review of the research is merely restricted in CNKI database, so the research coverage and depth is likely to be limited because of few samples; (2) The time span of the research is limited after 2007, so the research content is far from comprehensive; (3) Owing to the author's personal teaching experience and limited knowledge, the research approach is not diversified. Consequently, further researches should be conducted on the foundation of broader database, longer time length and more various approaches.

\section{Suggestion}

(1)To comply closely with the latest international development and trend of the research;

(2)To attach great importance to enhancing the instructors' level and practical skills;

(3)To pay close attention to the learners' learning outcome before entry and after graduation;

(4)To focus on the latest information technology employed in the research.

\section{Acknowledgement}

Fund Project: Funded by "the Study and Application of English Teaching Reform Based on Cloud Computing in Higher Vocational College", the project of the 12th Five-Year Plan in Hunan Province.

\section{References}

An, X. C., \& Zhou, L. (2010). Report on the Project of "English Curriculum Requirements for Higher Vocational and Technical Education". China English, 3-5.

Anuradha, A. G. (1995). Collaborative Learning Enhances Critical Thinking. Journal of Technology Education, 22-24.

Halliday, M. A. K. (1985). An Introduction to Functional Grammar. London: Edward Arnold.

Han, E. (2011). Analysis on the Reform of Vocational English Teaching. Journal of Hebei Radio and Television University, 63-65.

Kelly, G. (1963). A Theory of Personality. New York: Norton.

Li, L., Yang, D. X., \& Kong, J. (2007). On English Teaching Reform in higher vocational Colleges. Crazy English (Teachers), 67-68.

Little, D. (1991). Learner Autonomy: Definitions, Issues, and Problems. Dublin: Authentik.

Liu, S. J. (2015). English Teaching in Higher Vocational Colleges Influenced by English Skills Contest. Overseas English, 72-73.

Liu, X. L. (2009). On Function, Positioning, Present Situation and Reform of Higher Vocational English Teaching. Education Research and Experiment, 73-75.

Liu, X. Y. (2015). EOP Orientation for Higher Vocational English Teaching and Its Path Construction. Journal of Chengdu Normal University, 51-53.

Nelson, T. (1981). Literary Machines. Swarthmore: Pennsylvania.

Ning, S. Qi. (2012). On the Higher Vocational Education EOP English Teaching Mode and Practice of Its Path taking a case of Higher Vocational English Teaching Reform in Guangdong Province. Contemporary Foreign Language Study, 63-65.

Piaget, J., \& Garcia, R. (1987). Towards a Logic of Meanings. Translated. Hillsdale, NJ: Erlbaum.

Shao, J. F. (2016). On Professional Ability-Oriented Analysis of English Teaching Reform in Higher Vocational Colleges. Journal of Tianjin Teaching Institute, 84-86

The Ministry of Education. (2000). The Basic Requirements of English Curriculum Teaching in Higher Vocational College. Beijing: Higher Education Press.

Wei, Y. L. (2011). Thinking on reform of Higher Vocational English Teaching. Journal of Guangdong Agricultural, Industrial and technical college, 36-38.

Yang, S. K. (2010). On Grading Teaching of Higher Vocational English. Journal of Qiqihar University (Philosophy and Social Science Edition, 122-124. 
Zhang, M. (2009). English Skills Contest and Higher Vocational English Teaching. Forum of Higher Vocation, 60-62.

Zhang, X. H. (2010). Cademer's Philosophical Hermeneutics Theory and English Teaching Reform in Vocational Colleges. Jiujiang Vocational and Technical College, 36-38.

Zhou, T. (2011). On the Reform Direction for Higher Vocational English Teaching and Three Groups of Conflict Management. Journal of Changsha Railway Institute (Social Science Edition), 134-136.

\section{Copyrights}

Copyright for this article is retained by the author(s), with first publication rights granted to the journal.

This is an open-access article distributed under the terms and conditions of the Creative Commons Attribution license (http://creativecommons.org/licenses/by/4.0/). 